\title{
Література:
}

1. Моніторинг НУШ. Результати та рекомендації, перший етап, 2019-2020 pp. Оприлюднені 07 серпня 2020 року. - URL: https://mon.gov.ua/ua/news/oprilyudneno-rezultati-monitoringuvprovadzhennya-nush-reformu-pidtrimuyut-yak-batki-tak-i-pedagogi-uchnipilotnih-shkil-mayut-vishi-pokazniki-za-naskriznimi-uminnyami

2. Розпорядження кабінету міністрів України від 5 серпня 2020 року № 960-р «Про схвалення Концепції розвитку природничоматематичної освіти (STEM-освіти). - URL: https://zakon.rada.gov.ua/ laws/show/960-2020-\%D1\%80\#Text

3. Папач O.I. Науково-методичний супровід розвитку професійної компетентності вчителів в системі неперервної освіти. Професійна компетентність сучасного педагога: методологія, теорія, методика, практика: монографія. Одеса, 2019. С. 258-285.

DOI https://doi.org/10.30525/978-9934-588-80-8-2.20

\section{МЕТОДОЛОГИЧЕСКИЕ ОСНОВЫ ПОДГОТОВКИ БУДУЩИХ МАГИСТРОВ НЕПЕДАГОГИЧЕСКИХ ВУЗОВ К ПРОФЕССИОНАЛЬНО-ПЕДАГОГИЧЕСКОЙ ДЕЯТЕЛЬНОСТИ}

\section{Погорелая С. Г.}

кандидат педагогических наук, доцент кафедры славистической филологии, педагогики и методики преподавания Белочерковский национальный аграрный университет

Тимчук И. Н. кандидат педагогических наук, дочент кафедры славистической филологии, педагогики и методики преподавания

Белочерковский национальный аграрный университет г. Белая Церковь, Киевская область, Украина

Реформирование системы высшего образования Украины предполагает постоянное усовершенствование национальной системы образования, поиска эффективных путей улучшения качества услуг образования и внедрения инновационных педагогических систем. Соответственно, Национальной стратегией развития образования Украины с целью усиления кадрового потенциала системы образования одним из ключевых заданий педагогического образования отмечено 
«обеспечение подготовки педагогических работников по специальности «Профессиональное образование» (по профилю) для системы профессионально-технического образования...» Над теоретическими и методологическими основами повышения качества экономического образования работали О. Аксьонова, О. Вербило, Л. Савенкова, В. Свистун, В. Стрельников, С. Тарасова, В. Ярошинский и другие ученые.

Чтобы подготовить конкурентоспособного специалиста, высшее учебное заведение должно иметь высокопрофессиональный преподавательский состав, от уровня мастерства которого зависит результат профессиональной подготовки студентов и эффективность их личностного роста. Проблема профессионально-педагогической подготовки будущих магистров в высших непедагогических учебных заведениях является актуальной, поскольку современная система профессионального образования не обеспечивает надлежащей готовности выпускников магистратуры к преподаванию дисциплин цикла профессиональной подготовки. Выполняя обязанности научнопедагогического работника, вчерашний выпускник магистратуры принимает участие в различных видах деятельности: научноисследовательской, педагогической, организационной и воспитательной, что создает необходимость формирования у него во время учебы в университете знаний по методике преподавания дисциплин, индивидуально-психологических и возрастных особенностей студентов.

Нами были определены методологические подходы к профессионально-педагогической подготовке магистров непедагогических вузов. Так, личностно-ориентированный подход заключается в ориентации преподавателя в процессе профессионально-педагогической подготовки на личность как на цель, субьект, результат и главный критерий еффективности и продуктивности профессиональнопедагогической подготовки.

Личностно ориентированные воспитательные, учебные, образовательные технологии базируются на таких методологических принципах [109]: принцип целенаправленного создания эмоционально обогащенных воспитательных ситуаций; принцип личностно развивающего общения; принцип использования сопереживания как психологического механизма в воспитании личности; принцип систематического анализа преподавателем собственных и чужих поступков.

По исследованиям С. Сысоевой, целью и результатом личностно ориентированного обучения должен быть молодой человек, который является компетентной личностью, а следовательно способным не только адаптироваться к требованиям современного общества и рынка труда, но и личностно и профессионально реализоваться в течение жизни [111, с. 13]. 
Использование коммуникативного подхода предполагает овладения будущими магистрами навыками профессионально-педагогического общения.

По нашему мнению, цель реализации коммуникативного подхода овладение соискателями второго (магистерского) уровня умениями профессионально-педагогического общения, состоящие из взаимосвязанных коммуникативных, перцептивных и интерактивных умений. Для воплощения коммуникативного подхода нужно обеспечить соответствующую мотивацию и создавать проблемные ситуации, порождать потребность в общении и решении определенных проблем. Коммуникативная активность студентов имеет важное практическое значение для создания благоприятных условий и оптимизации учебной деятельности.

Важным критерием эффективности профессиональной подготовки будущих магистров есть сформированность практических умений, что определяет применение деятельностного подхода в профессиональнопедагогической подготовке.

Английский философ-экономист Хайек утверждал, что деятельность провоцирует стремление к успеху, она в определенном смысле сама по себе является «технологией успеха». Поэтому именно деятельностный подход является критерием успешности обучения и дальнейшей жизни [123].

Контекстный подход заключается в организации учебного процесса в контексте будущей профессиональной деятельности с помощью включения в формы и методы учебной деятельности студентов реальных связей и отношений, решение конкретных профессиональных задач.

Будущий магистр непедагогического вуза должен овладеть всеми тонкостями методологической основы преподавания дисциплин цикла профессиональной подготовки, в основе которой лежат методологические подходы, чтобы творчески руководя учебным процессом, понятно и убедительно смог донести содержание науки, ее профессиональную направленность и удовлетворить творческие и практические интересы студентов.

Основными характеристиками контекстного обучения является то, что субъект обучения с самого начала ставится в деятельностную позицию, предмет которой постепенно превращается из чисто учебного в практико-профессиональный; требования со стороны профессиональной деятельности является системообразующими, они задают контекстный принцип построения и развертывания не только отдельных учебных дисциплин, но и содержание всей подготовки преподавателя в вузе $[127$, c. 69].

\section{Литература:}

1. Бех І. Д. Особистісно зорієнтоване виховання : наук.-метод. посіб. Київ : ІЗМН, 1998. 204 с. 
2. Сисоєва С. О. Педагогічні технології професійної підготовки фахівців : навч. тренінг : навч.-метод. посіб. Київ : Університет «Україна», 2007. 185 с.

3. Пометун О. І. Методика навчання історії в школі . Київ : Генеза, 2005. $328 \mathrm{c}$.

4. Скворцова С. О. Формування професійної компетентності майбутнього вчителя на засадах контекстного навчання. Психологопедагогічні проблеми сільської школи : зб. наук. прачь Уман. держ. пед. ун-ту ім. Павла Тичини. 2010. Вип. 35. С. 66-71.

DOI https://doi.org/10.30525/978-9934-588-80-8-2.21

\title{
ОСВІТНІ ТЕХНОЛОГІЇ В ПРОЦЕСІ \\ ФОРМУВАННЯ КУЛЬТУРНОЇ ГРАМОТНОСТІ СТУДЕНТІВ ЗАСОБАМИ АНГЛІЙСЬКОЇ МОВИ
}

\author{
Полєжаєв Ю. Г. \\ кандидат наук із соиіальних комунікацій, доцент, \\ дочент кафедри іноземних мов професійного спілкування \\ Національний університет «Запорізька політехніка» \\ м. Запоріжжя, Украйна
}

Метою роботи $\epsilon$ висвітлення теоретичних аспектів використання освітніх технологій у процесі формування культурної грамотності в майбутніх фахівців. Стійкі модернізаційні тенденції зумовили впровадження інноваційних методів і форм навчання студентів, виокремлення нових аспектів компетентності випускників закладів вищої освіти й напрямків та шляхів іiі формування. У контексті глобалізації актуалізується потреба в підготовці фахівців 3 високим рівнем культурної грамотності. Проте, проблеми вищої школи в Україні сьогодні - це значна невідповідність стандартам Свропейського Союзу, зниження якості підготовки майбутніх фахівців, наявність суперечностей між умовами навчання й вимогами часу, застосування застарілих освітніх технологій, недостатній рівень інформатизації в охопленні всіх без виключення сегментів освітнього процесу тощо.

Під ідеєю технологізації освіти розуміють правильне визначення мети, підбір засобів ііі досягнення, створення правил користування ними. Педагогічні технології, безумовно, інтегрують у теорію та практику освіти. Вони $€$ змістовною технікою реалізації освітнього процесу.

Серед основних ознак педагогічної або освітньої технології структурність, оптимальність, конкретність, діагностичність тощо. Правильний вибір педагогічної технології 3 метою формування культурної 